\title{
PENGEMBANGAN KAPASITAS PEREMPUAN BAGI IBU-IBU RELAWAN PROGRAM PALIATIF DI DESA KAMBINGAN DAN DESA KREMBUNG, KECAMATAN CERME, KABUPATEN GRESIK
}

\section{(WOMEN'S CAPACITY BUILDING FOR VOLUNTEERS IN THE PALLIATIVE PROGRAM IN KAMBINGAN AND KREMBUNG, CERME, GRESIK)}

\author{
Sulikah Asmorowati ${ }^{1}$, Inge Dhamanty ${ }^{2}$ \\ ${ }^{1}$ Departemen Administrasi Negara FISIP, ${ }^{2}$ Departemen Administrasi dan Kebijakan \\ Kesehatan. FKM Universitas Airlangga \\ e-mail: sulikah.asmorowati@fisip.unair.ac.id
}

\begin{abstract}
The high rate of deaths caused by serious illnesses has led the World Health Organization (WHO) to recommend palliative care that is considered to be able to improve the quality of patient's live Palliative care or service is service for patients with serious illnesses, such as cancer (stadium or end-stage). In this activity, however, palliative care and service is extended so that it includes diseases that are not contagious but deadly (thus, contributed significantly to mortality rate), including such illnesses as diabetes, high-blood pressure, cholesterol, stroke and other similar illnesses. These illnesses are now increasingly being suffered by and become the major cause of death (caused by illnesses) amongst Indonesians. In order to increase the availability of palliative services in the target area, this community project provides training and assistance to develop women's capacity in the villages of Kambingan and Ngembung, Cerme, Gresik, so that they are ready to volunteers for palliative care and service in their respective communities. The projects were conducted by providing material through lectures, and modules; followed by assistance to form a team of palliative case and service. At the end, this project resulted in the increasing understanding, and capacity of women (and mothers or PKK member), as the target groups about palliative care and services. In turn, the women were then ready to become volunteers for palliative care and program.
\end{abstract}

Keywords: capacity building, Palliative service, palliative volunteer, women

abstrak

Tingginya tingkat kematian akibat penyakit serius membuat WHO menyarankan untuk melakukan perawatan paliatif yang dianggap dapat meningkatkan kualitas hidup pasien. Program atau layanan paliatif adalah pelayanan kepada pasien dengan penyakit berat, yaitu kanker (stadium akhir). Dalam kegiatan pengabdian masyarakat (pengmas) ini, layanan paliatif diperluas sehingga meliputi pula penyakit-penyakit yang tidak menular namun mematikan, seperti penyakit diabates, darah tinggi, kolesterol, stroke dan sejenisnya yang dewasa ini semakin banyak di derita masyarakat Indonesia. Kegiatan pengmas ini memberikan pelatihan dan pendampingan untuk mengembangkan kapasitas ibu-ibu tim penggerak dan anggota PKK di Desa Kambingan dan Desa Ngembung, Kecamatan Cerme, Kabupaten Gresik agar siap untuk menjadi relawan program paliatif di lingkungan masyarakat masing-masing. Metode yang digunakan dalam kegiatan ini adalah dengan pemberian materi melalui ceramah, pemberian modul, serta pendampingan pembentukan tim paliatif sebagai follow-up kegiatan. Hasil yang dicapai dari kegiatan pengabdian masyarakat ini adalah meningkatnya pemahaman masyarakat khususnya ibu-ibu tentang layanan paliatif, serta meningkatnya kapasitas mereka,sehingga siap menjadi relawan program paliatif.

Kata Kunci: Layanan paliatif, relawan program paliatif, pengembangan kapasitas, perempuan 


\section{PENDAHULUAN}

Seiring dengan perkembangan teknologi, perubahan gaya hidup, dan pola makan, semakin banyak orang yang mengalami penyakit kronis bahkan di usia yang masih muda. Data dari World Health Organization (WHO), menunjukkan bahwa 38 juta orang yang meninggal dunia setiap tahunnya dikarenakan penyakit tidak menular (namun mematikan), seperti diabetes, darah tinggi, jantung, kolesterol dan penyakit degeneratif lain/sejenis. Bahkan penyakit-penyakit ini telah dialami oleh 16 juta jiwa orang, sebelum mereka berusia 70 tahun dan menyebabkan kematian dini sebanyak $82 \%$. Penyakit kardiovaskular, penyakit jantung serta pembuluh darah-adalah penyebab utama yang menyebabkan tingkat kematian dini di dunia. Kemudian disusul dengan penyakit kanker yang telah meningkat kejadiannya hingga 70\% selama 2 dekade terakhir, lalu diabetes dan penyakit pernapasan. Tingginya tingkat kematian akibat penyakit-penyakit serius ini membuat WHO menyarankan untuk melakukan perawatan paliatif yang dianggap dapat meningkatkan kualitas hidup pasien. WHO lebih lanjut menegaskan bahwa setiap orang di dunia berhak untuk mendapatkan perawatan yang paling baik walaupun di masa-masa akhir hidupnya. Menurut WHO, diperkirakan setiap tahun terdapat 19 juta pasien yang membutuhkan perawatan paliatif. Namun, tenaga kesehatan yang bergerak dalam bidang paliatif masih sangat jarang. Menurut Sunaryadi (2017), spesialis paliatif selama ini hampir selalu dicetak melalui pendidikan luar negeri dengan biaya pendidikan yang mahal. Hal ini lebih lanjut berakibat pada minimnya jumlah spesialis paliatif di Indonesia. Di Surabaya, misalnya meskipun merupakan ibukota Provinsi Jawa Timur hanya ada 16-17 spesialis paliatif). Dari jumlah yang ada, usia para spesialis tersebut juga tidak lagi muda. Maka dari itu, penting bagi stakeholder kesehatan untuk memperluas jaringan pemberdayaan masyarakat dalam bidang paliatif.

Secara konsep, layanan paliatif adalah layanan yang ditujukan untuk penderita penyakit berat ataupun penyakit yang memiliki kesempatan hidup rendah. Layanan ini merupakan perawatan kesehatan yang bersifat terpadu, aktif dan menyeluruh, dengan pendekatan multidisiplin dan terintegrasi. Lebih jelas tentang pelayanan paliatif bisa dilihat pada gambar berikut:

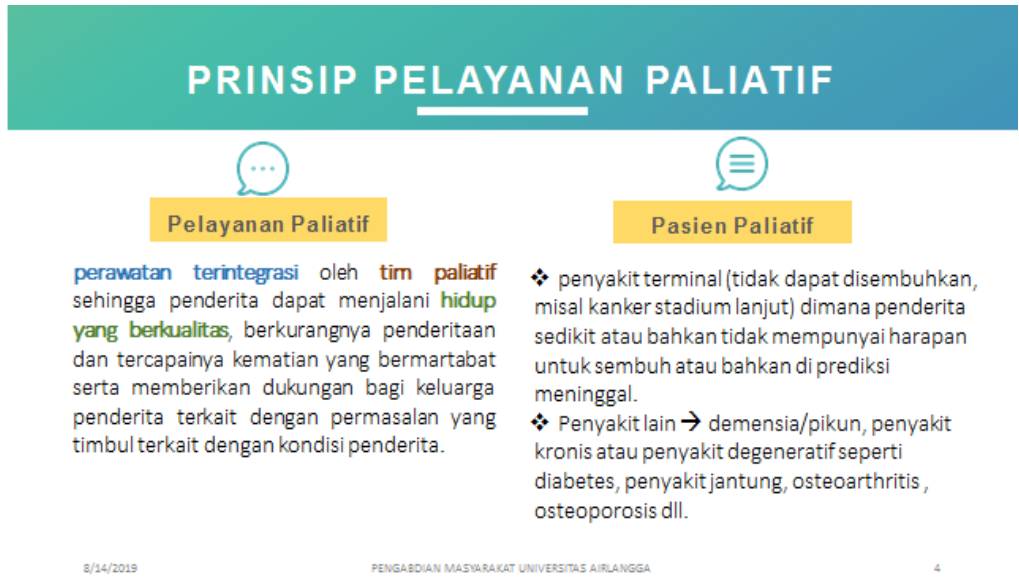

Gambar 1. Prinsip Pelayanan Paliatif

Sumber: Modul TOT Paliatif Kanker Bagi Tenaga Kesehatan, Kementerian Kesehatan Republik Indonesia 
Singkatnya, cakupan pelayanan atau program paliatif bukan hanya medis, namun meliputi ranah sosial, ekonomi, dan religi. Perawatan paliatif bertujuan untuk meningkatkan kualitas hidup pasien serta meminimalkan beban rasa sakit dan/atau mengurangi rasa nyeri dan penderitaan lain. Di rumah sakit, pelayanan paliatif, meliputi penatalaksanaan nyeri, penatalaksanaan keluhan fisik lain, asuhan, keperawatan, dukungan psikologis, dukungan social dan dukungan kultural dan spiritual, serta dukungan persiapan dan selama masa dukacita (bereavement). Dalam kegiatan Pengabdian Masyarakat (pengmas) ini, layanan paliatif diperluas sehingga meliputi pasien yang menderita penyakit tidak menular namun mematikan seperti diabetes, darah tinggi, jantung maupun kolesterol dan stroke dan penyakit degeneratif lain.

Menariknya, upaya meningkatan dan memperluas pelayan paliatif kepada masyarakat, juga melibatkan relawan paliatif yang berasal dari segala disiplin ilmu dan pekerjaan. Relawan ini terutama direkrut untuk melakukan perawatan dengan kunjungan rumah pada orang-orang yang membutuhkan penanganan paliatif. Relawan ini tentunya bukan untuk pelayanan yang bersifat medis, namun lebih untuk memberikan dukungan spiritual dan psikososial. Lewat penanganan ini relawan diharapkan dapat memotivasi penderita agar lebih memandang positif penyakitnya, serta membantu keluarga pasien agar bisa lebih memahami kondisi pasien, mengerti penyakit yang diderita si sakit, sekaligus siap menghadapi segala sesuatu yang mungkin terjadi pada diri pasien (Sofiana, 2016).

Merujuk pada lokus kegiatan pengabdian ini, sebagaimana dilansir oleh Departemen Kesehatan RI dalam Surat Kabar Jawa Pos, 26 Desember 2017, seluruh rumah sakit di Kota Gresik, berencana membuka layanan poli paliatif. Program ini dicanangkan untuk dimulai pada tahun 2018 lalu, namun hingga saat ini pelaksanaannya terkesan kurang optimal. Sementara penderita penyakit yang memerlukan pelayanan paliatif di Gresik cukup besar. Hingga Nopember 2017, tercatat 782 orang yang mengidap kanker serviks, 14 orang menderita kanker payudara, serta 8 dari 49 orang dengan indikasi mengalami benjolan dicurigai menderita tumor dan bahkan kanker, baik kanker paruparu, tuang maupun prostat (Jawa Pos, 26 Desember 2017). Berdasarkan kecenderungan kurangnya pelayanan program paliatif di kota Gresik, kegiatan pengabdian kepada masyarakat ini berfokus pada optimalisasi Perawatan paliatif melalui upaya penyiapan sumber daya relawan yang akan berpartisipasi aktif dalam pengembangan pelayanan paliatif. Kenyataannya, pelayanan paliatif adalah pelayan sosial yang tidak mendatangkan banyak keuntungan, sehingga di Indonesia, khususnya di Gresik pelayanan ini belum optimal. Pelayanan paliatif yang banyak saat ini, hanya terbatas pada dengan metode HHC (Hospice Home Care) atau dengan mengunjungi rumah pasien yang kebanyakan dikhususkan untuk penderita kanker, stroke, dan Alzheimer, dan kebanyakan melibatkan atau dilakukan oleh relawan. Oleh karena itu, kegiatan pengabdian kepada masyararakat ini berfokus pada peningkatan kapasitas perempuan sehingga semakin banyak perempuan yang siap menjadi relawan program paliatif. Intervensi paliatif, seharusnya juga diberikan untuk penanganan penyakitpenyakit yang banyak dikeluhkan dan diderita oleh anggota masyarakat; termasuk khususnya di daerah yang menjadi sasaran kegiatan pengabdian ini, yaitu di Desa Kambingan dan Desa Ngembung, di Kecamatan Cerme, Kabupaten Gresik, yaitu penyakit yang tidak menular namun mematikan. kegiatan pengabdian kepada masyarakat yang berfokus pada perempuan. Dapat dilihat pada gambar berikut: 


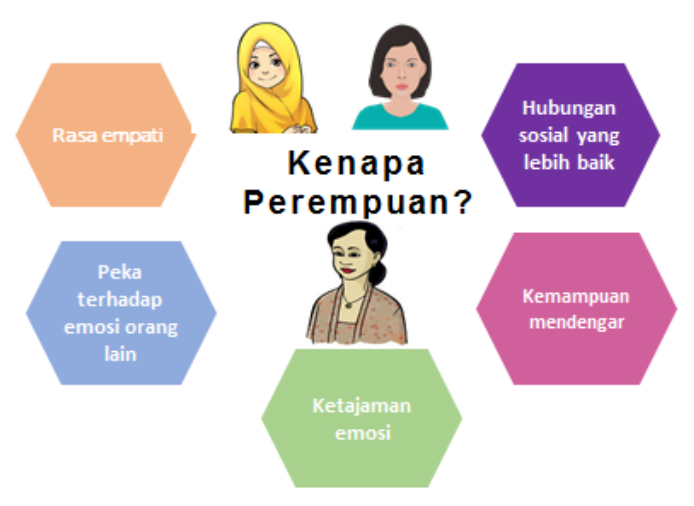

Gambar 2. Relawan Program Paliatif

Sumber: Wymer, W., Gender differences in social support in the decision to volunteer. International Review on Public and Nonprofit Marketing.

Sehingga dalam hal ini dapat meningkatkan peran perempuan dalam pembangunan, khususnya di bidang kesehatan. Sebagaimana debat tentang perempuan dalam pembangunan, Women in Development, dan yang terakhir, Gender and Development, perempuan memiliki andil yang besar dalam pembangunan di suatu Negara. Dalam peran gender ini kesetaraan dan kebersamaan laki-laki dan perempuan dalam pembangunan sangat ditekankan (Riant Nugroho, 2008:25). Untuk itu, kegiatan pengabdian ini menjadi salah satu bentuk nyata untuk mewujudkan kontribusi perempuan dalam pembangunan, khususnya di bidang kesehatan.

Informasi dari anggota tim penggerak PKK kecamatan, diketahui bahwa dalam upaya mencegah dan menanggulangi semakin tingginya prevalensi penyakit di Kabupaten Gresik, Ketua Tim penggerak PKK Kabupaten Gresik, Maria Ulfa Sambari, sedang gencar mengkampanyekan Deteksi Penyakit Tidak Menular tapi Mematikan." Sejalan dengan permasalahan umum tersebut, kegiatan pengabdian kepada masyarakat ini berupaya untuk meningkatkan kapasitas perempuan dalam program paliatif yang dikaitkan dengan penyakit yang tidak menular namun mematikan dimana hal tersebut berpengaruh pada kondisi psikologis penderita. Berikut pengaruh kondisi pederita secara psikologis dijelaskan dalam gambar berikut:

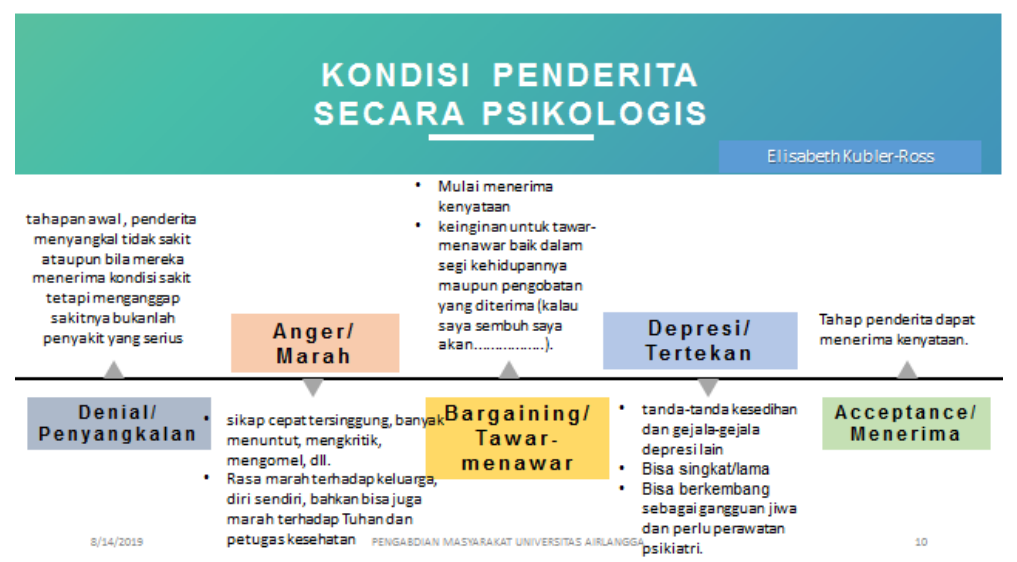

Gambar 3. Kondisi Penderita secara Psikologis

Sumber: Mesch, Rooney, Steinberg, and Denton 2006; Wymer and Samu 2002 
Hal ini juga yang menjadi pertimbangan bahwa program atau layanan paliatif dalam kegiatan pengabdian ini tidak hanya terbatas pada penyakit kanker atau penyakitpenyakit stadium akhir lain, tapi juga penyakit yang tidak menulat namun mematikan seperti, hipertensi atau darah tinggi, diabetes, jantung, stroke serta penyakit lain yang memerlukan intervensi atau layanan paliatif. Kegiatan peningkatan kapasitas ini dilakukan dengan dua mitra PKK, yaitu tim penggerak dan anggota PKK di Desa Ngembung dan Desa Kambingan, Kecamatan Cerme, sehingga para perempuan ini siap menjadi relawan-relawan paliatif yang berkontribusi pada perbaikan kesehatan masyarakat di wilayahnya. Kegiatan ini dilatarbelakangi oleh permasalahan yang dihadapi oleh mitra, yaitu Kecamatan Cerme, khususnya di dua desa dimana angka penderita penyakit tidak menular namun mematikan tersebut cukup tinggi. Sebagaimana data dari puskesmas setempat, di Desa Ngembung, misalnya, pada bulan Februari 2018, terdapat penyebaran penyakit berat sebagai berikut:

Tabel 1. Penyakit Berat di Desa Ngembung Bulan Februari 2018

\begin{tabular}{lll}
\hline Penyakit & Laki-Laki & $\begin{array}{c}\text { Jumlah } \\
\text { Perempuan }\end{array}$ \\
\hline $\begin{array}{l}\text { Diabetes (Kencing } \\
\text { Manis) }\end{array}$ & 22 & 26 \\
Hipertensi & 15 & 22 \\
Jantung & 3 & 3 \\
Kanker Rahim & - & 1 \\
Tumor Otak & - & 1 \\
\hline
\end{tabular}

Sumber: Bidan Desa Ngembung

Survey awal di Desa Kambingan juga diperoleh hasil yang senada, yaitu penyakit serupa di desa Kambingan juga cukup besar (Informasi staf Kecamatan Cerme, 2018). Penyakit - penyakit ini tidak menular, namun semakin umum dan banyak diderita individual yang bisa berujung pada kematian. Selain penyakit tersebut dalam tabel, penyakit kolesterol dan bahkan stroke juga semakin umum di dua desa mitra. Kenyataannya penyakit-penyakit yang tidak menular ini diderita seumur hidup oleh penderitanya, atau jika tidak seumur hidup, memerlukan masa penyembuhan yang cukup lama, sehingga sering kali penderita menjadi tidak bersemangat, putus asa dan bereaksi negatif terhadap penyakitnya. Hal ini lebih lanjut memperlambat kesembuhan dan sebaliknya mempercepat kematian pasien. Di sinilah program dan pelayanan paliatif memegang peran yang besar dalam memotivasi penderita agar lebih positif terhadap penyakit mereka. Keaktifan tim penggerak dan anggota PKK di dua desa tersebut perlu diperkuat, mengingat mereka menjadi tulang punggung desa untuk berpartisipasi aktif di masyarakat. Selain itu, yang terkait secara langsung dengan fokus kegiatan pengabdian ini adalah mereka tidak mengetahui tentang program paliatif, sementara di sisi lain banyak masyarakat di sekitar mereka yang menderita penyakitpenyakit yang tidak menular tersebut yang merasa putus asa karena beranggapan 
penyakit mereka tidak bisa disembuhkan, ditambah dengan ketergantungan pada obatobatan dengan pantangan makanan yang tidak mudah.

Pilihan pada dua desa sasaran, yaitu Desa Ngembung dan Desa Kambingan, dikarenakan dua desa ini bisa menjadi percontohan yang akan membina desa lain di sekitarnya. Selain itu, pilihan dua desa ini juga berbasis pada aspek gender, khususnya fokus pada perempuan dalam kegiatan pengabdian ini. Penyakit kronis serta penyakit tidak menular yang mematikan yang dialami pasien telah menyebabkan berbagai hal. Dampaknya tidak hanya pada kesehatan saja, namun mempengaruhi semua aspek kehidupan pasien. Oleh karena itu, perawatan paliatif dilakukan untuk mengurangi dampak lain yang mungkin timbul karena penyakit yang diderita pasien.

Pertama gangguan fisik, seperti nyeri, susah tidur, napas menjadi pendek, tidak nafsu makan, dan merasa sakit pada perut. Berbagai hal tersebut sering kali dirasakan oleh pasien penyakit kronis yang sudah berada di stadium akhir. Lalu, yang bisa dilakukan untuk mengatasi hal tersebut adalah melakukan konseling gizi, melakukan terapi fisik, serta memberikan teknik bagaimana mengambil napas dalam-dalam agar tubuh menjadi lebih rileks. Dalam hal ini, relawan bisa berperan, namun jika tidak sanggup bisa menghubungkan pasien dengan ahli gizi atau tenaga medis yang relevan.

Kedua adalah gangguan emosi dan sosial. Tentunya menderita suatu penyakit serius akan membuat pasien merasa takut, marah, sedih, emosi tidak terkontrol, dan depresi. Begitupun dengan keluarga pasien yang juga merasakan hal yang sama. Dalam perawatan paliatif, hal ini dapat dikurangi dengan cara melakukan konseling, membuat diskusi antar-sesama pasien yang memiliki riwayat penyakit yang sama, dan pertemuan keluarga.

Ketiga adalah problem finansial. Tidak bisa dipungkiri bahwa ketika menderita sakit, Anda dan keluarga tidak hanya harus siap mental dan fisik saja, namun dari segi keuangan juga harus diperhatikan. Penyakit serius tentunya menyebabkan pengeluaran untuk biaya pengobatan yang cukup besar. Oleh karena itu dalam perawatan paliatif ini, tim perawat harus menjelaskan seberapa besar biaya yang diperlukan untuk pengobatan, sebelum pengobatan tersebut dilakukan. Tidak hanya itu, tim perawat dan relawan paliatif juga harus memberikan konseling terkait keuangan.

Keempat adalah masalah spiritual. Ketika seseorang mengalami penyakit yang serius maka mereka akan mencari kedamaian serta ketenangan. Tim relawan paliatif akan menolong pasien untuk menemukan kedamaiannya, dan biasanya melibatkan tokoh masing-masing agama yang dipercayainya.

\section{METODE PENGABDIAN MASYARAKAT}

Untuk menjawab permasalahan mengenai tingginya tingkat kematian akibat penyakit serius dan membuat WHO menyarankan untuk dilakukannya perawatan paliatif yang dianggap dapat meningkatkan kualitas hidup pasien, namun jumlah tenaga kesehatan perawat paliatif yang terbatas maka masyarakat khususnya kaum perempuan turut dilibatkan sebagai relawan program paliatif. Kegiatan pengabdian masyarakat ini mengambil judul Pengembangan Kapasitas Perempuan bagi Ibu-Ibu Relawan Program 
Paliatif di Desa Kambingan dan Ngembung Kecamatan Cerme Kabupaten Gresik. Hal ini mengingat pentingnya peran perempuan sebagai relawan dalam program paliatif dan untuk meningkatkan kapasitas perempuan sebagai relawan program paliatif.

Untuk mencapai tujuan-tujuan tersebut, metode yang digunakan dalam kegiatan pengabdian masyarakat ini adalah sebagai berikut :

\section{Pemberian materi melalui ceramah.}

Materi pelatihan atau ceramah ini meliputi penjelasan mengenai program paliatif, termasuk apa itu program paliatif, prinsip-prinsip dalam perawatan paliatif, peran relawan dalam perawatan paliatif, pemberian dukungan psikologi, sosial dan spiritual, cara berkomunikasi yang efektif sebagai relawan program paliatif, cara memberi dukungan dalam menghadapi kematian atau duka cita dan juga self-care (perawatan diri relawan). Materi disampaikan secara terstruktur, serius tapi santai dan disesuaikan dengan kapasitas relawan dari Ibu-Ibu Tim Penggerak dan Anggotan PKK di kedua desa yang menjadi objek kegiatan pengabdian masyarakat ini sehingga materi yang disampaikan lebih mudah diserap dan dipahami oleh kelompok sasaran atau mitra dalam kegiatan pengabdian masyarakat.

\section{Pembuatan dan pemberian modul.}

Untuk mendukung kegiatan pengabdian masyarakat ini maka dibuatkan Modul Peningkatan Kapasitas Perempuan sebagai Relawan dalam Program Paliatif dan selanjutnya modul tersebut diberikan kepada setiap relawan program paliatif dari Desa Ngembung dan Desa Kambingan yang hadir pada saat kegiatan pengabdian masyarakat ini berlangsung agar para relawan menjadi lebih mudah memahami apa dan bagaimana yang bisa dikerjakan sebagai relawan program paliatif sehingga hasil yang diharapkan dari kegiatan pengabdian masyarakat ini yakni meningkatnya kapasitas perempuan yang siap menjadi relawan dalam program paliatif dapat terwujud.

\section{Pendampingan Sebagai Follow-up Program}

Untuk tercapainya pelaksanaan dua metode ini, maka dilakukan perencanaan kegiatan, yaitu: 1) Koordinasi dengan tim pelaksana (Dua tim dosen dan anggota) serta tim pendukung kegiatan pengabdian masyarakat yang terdiri dari empat mahasiswa aktif Program Studi Administrasi Negara; 2) Koordinasi dengan mitra pemberdayaan masyarakat, dalam hal ini adalah Kepala Desa, Bidan Desa dan Ketua Tim Penggerak PKK Desa Ngembung dan Desa Kambingan Kecamatan Cerme Kabupaten Gresik untuk menentukan waktu dan tempat pelaksanaan kegiatan pengabdian masyarakat; 3) Mengurus surat perijinan ke mitra terkait, yaitu Kepala Desa dan Ketua Tim Penggerak PKK Desa Ngembung dan Desa Kambingan Kecamatan Cerme Kabupaten Gresik; 4) Koordinasi dengan Kepala Desa, Bidan Desa dan Ketua Tim Penggerak PKK Desa Ngembung dan Desa Kambingan Kecamatan Cerme Kabupaten Gresik untuk persiapan pelaksanaan kegiatan pengabdian masyarakat; 5) Mempersiapkan segala keperluan yang diperlukan untuk melakukan kegiatan pengabdian masyarakat, misalnya memperbanyak modul yang akan diberikan beserta ATK dan persiapan konsumsi yang akan diberikan pada saat kegiatan ceramah materi selesai dilakukan.

Kemudian mitra yang turut andil dalam kegiatan pengabdian masyarakat ini adalah IbuIbu Tim Penggerak dan Anggota PKK dari Desa Ngembung dan Desa Kambingan 
Kecamatan Cerme Kabupaten Gresik. Partisipasi mitra dalam kegiatan pengabdian ini adalah: 1) Menyediakan tempat untuk kegiatan ceramah dalam hal ini bertempat di Balai Desa Ngembung dan Balai Desa Kambingan; 2) Menyiapkan para peserta pelatihan, yaitu Ibu-Ibu Penggerak dan Anggota PKK Desa Ngembung dan Desa Kambingan Kecamatan Cerme Kabupaten Gresik; 3) Bersedia untuk menjadi relawan program paliatif. Selain itu juga bersedia untuk membagikan ilmu yang didapat selama kegiatan ini berlangsung kepada masyarakat lain yang tidak ikut dalam kegatan pengabdian masyarakat.

\section{HASIL DAN PEMBAHASAN}

Seperti telah dijelaskan dalam Bab Metodologi, kegiatan pengabdian kepada masyarakat yang secara umum bertujuan untuk meningkatkan kapasitas Ibu-Ibu Tim Penggerak dan Anggota PKK agar siap menjadi relawan program paliatif dan secara khusus, target dari kegiatan pengabdian masyarakat adalah agar kelompok sasaran mampu memahami pentingnya dukungan psikologis dan psikis, serta penanganan program paliatif yang menjadi tupoksi relawan program paliatif. Kegiatan ini dilaksanakan dengan dua cara yaitu pelatihan dan pendampingan ibu-ibu anggota PKK yang menjadi relawan paliatif.

\section{Peserta}

Kegiatan pelatihan dalam rangka peningkatan kapasitas perempuan sebagai relawan dalam program paliatif ini mengundang 28 orang yang terdiri dari Kepala Desa, Bidan Desa dan perwakilan anggota PKK Desa Ngembung. Sedangkan untuk mitra dari Desa Kambingan dihadiri oleh 23 orang yang terdiri dari Kepala Desa, Bidan Desa dan perwakilan anggota PKK Desa Kambingan Kecamatan Cerme Kabupaten Gresik "mengenai pesta srada, Pararaton hanja menjinggung dalam satu baris sadja. Beritanja terlalu singkatdan hanja menjebut bahwa prabu Hajam Wuruk pada tahun Saka 1284 mengadakan pesta srada." (Muljono, 1965)

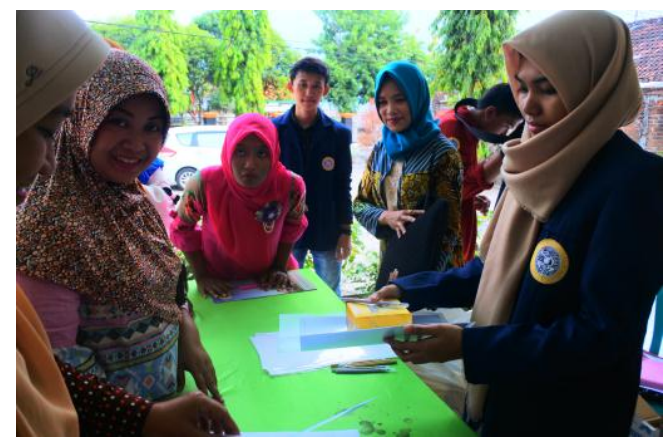

Gambar 4. Peserta Program Paliatif

Dari keseluruhan peserta yang berada di dua lokasi kegiatan pengabdian masyarakat yang hadir sangat antusias mengikuti pelatihan/ceramah yang diberikan oleh Ketua Pengusul kegiatan pengabdian masyarakat. Antusiasme ini terlihat dari kehadiran ibuibu anggota PKK yang sudah siap dilokasi pelatihan dan banyaknya pertanyaan yang dilontarkan oleh para peserta yang hadir.

Gambaran Pelaksanaan Kegiatan

Kegiatan pengembangan dan peningkatan kapasitas perempuan sebagai relawan dalam program paliatif ini memberikan pelatihan kepada peserta melalui ceramah dan 
pemberian Modul Peningkatan Kapasitas Perempuan sebagai Relawan dalam Program Paliatif di dua desa, yakni Desa Ngembung dan Desa Kembangan

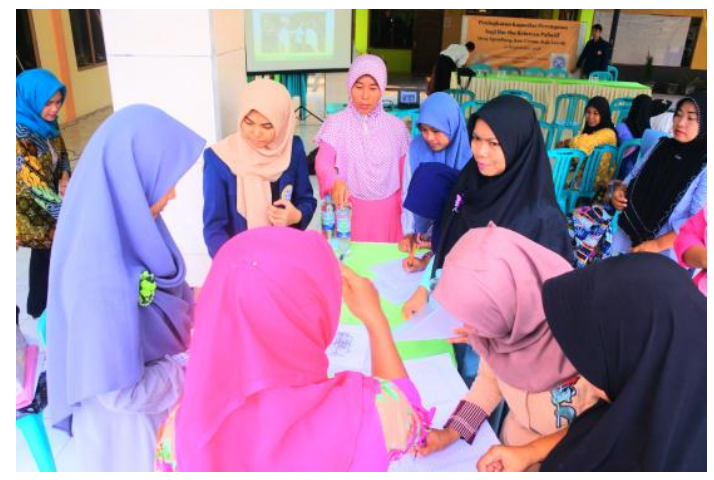

Gambar 5. Pelaksanaan Pengabdian Masyarakat

\section{Pemberian Materi Melalui Pelatihan/Ceramah}

Pemberian ceramah ini telah dilakukan oleh Ketua Pengusul Pengabdian Masyarakat (Sulikah Asmorowati, S.Sos., M.DevSt., Ph.D) yang membahas secara umum tujuan dan materi pengabdian, dilanjutkan dengan narasumber kedua tentang Pengembangan Kapasitas (Capacity building) yang dilakukan oleh Putu Aditya, SIP., MKP. Materi terakhir membahas topik inti yaitu Peningkatan Kapasitas Perempuan sebagai Relawan dalam Program Paliatif, dengan durasi 2 jam dilakukan bersama antara Sulikah Asmorowati dan Putu Aditya. Kegiatan dilakukan pada tanggal 10 September 2018 pukul 15.00-18.00 WIB di Desa Ngembung Kecamatan Cerme Kabupaten Gresik. Materi ceramah yaitu mengenai penjelasan mengenai program paliatif, termasuk apa itu program paliatif, prinsip-prinsip dalam perawatan paliatif, peran relawan dalam perawatan paliatif, pemberian dukungan psikologi, sosial dan spiritual, cara berkomunikasi yang efektif sebagai relawan program paliatif, cara memberi dukungan dalam menghadapi kematian atau duka cita dan juga self-care (perawatan diri relawan). Serta contoh-contoh yang terjadi di lingkungan sekitar yang bisa diambil pelajarannya yang berkaitan dengan program paliatif. Materi disampaikan secara terstruktur, serius tapi santai dan disesuaikan dengan kapasitas relawan dari Ibu-Ibu Tim Penggerak dan Anggotan PKK di kedua desa yang menjadi objek kegiatan pengabdian masyarakat ini sehingga materi yang disampaikan lebih mudah diserap dan dipahami oleh kelompok sasaran atau mitra dalam kegiatan pengabdian masyarakat. Kegiatan yang sama dilakukan di Desa Kambingan, Kecamatan Cerme, Kabupaten Gresik pada tanggal 17 September. Sama dengan kegiatan di Desa Ngembung, terdapat 3 materi yang disampaikan oleh tiga narasumber. Acara berlansung dari pukul 19.00-22.00. Pemberian Modul Peningkatan Kapasitas Perempuan sebagai Relawan dalam Program Paliatif.

Modul ini diberikan kepada setiap perserta yang hadir dalam kegiatan pengabdian masyarakat dan dimasukkan ke dalam map plastik untuk menjaga agar modul tersebut tetap terjaga dalam jangka waktu yang lama serta dilengkapi dengan perlengkapan ATK berupa bolpen untuk memudahkan para peserta ketika ingin mencatat materi yang dirasa penting dan perlu dicatat. Modul berisi materi yang mudah difahami oleh para peserta karena disesuaikan dengan latar belakang dan tingkat pendidikan peserta yang berbedabeda agar semua peserta dapat menerima dan memahami materi yang ada di dalamnya. Modul tersebut diberikan langsung kepada para peserta pada saat peserta menulis daftar 
hadir sehingga ada kesempatan bagi peserta untuk membaca dan mempelajari isi modul lebih awal sebelum sesi ceramah dimulai.

Dari kegiatan pengabdian masyarakat di dua desa tersebut, pada dasarnya mereka menyambut dengan antusias pelatihan yang diberikan dan sangat gembira bahwa mereka yang hadir pada saat itu bisa menjadi relawan program paliatif. Modul yang diberikan membantu dan menjadi pedoman mereka dalam menjadi relawan program paliatif karena sebelum kegiatan pengabdian masyarakat ini dilakukan, mereka belum pernah mendapatkan pelatihan semacam ini dan mereka baru mengetahui mengenai program paliatif. Satu hal yang menjadi kendala ibu-ibu relawan adalah mengenai komunikasi dengan penderita penyakit atau keluarga penderita. Kebanyakan kasus yang terjadi adalah si penderita penyakit ataupun keluarga penderita tidak mau mengkomunikasikan mengenai sakit apa yang sedang diderita. Mereka merasa malu untuk mengkomunikasikan kepada para relawan dan menganggap bahwa apabila mereka mengkomunikasikan kepada relawan sama saja dengan mereka membongkar aib mereka sendiri. Hal ini menyulitkan relawan dalam memberikan bantuan atau menanangi mereka dengan menggunakan program paliatif yang ada, karena para relawan tidak tahu permasalahan apa yang dihadapi oleh penderita penyakit atau keluarga penyakit sehingga para relawan pun tidak bisa memberikan solusi untuk mengatasi permasalah yang diderita si penderita atau keluarga si penderita. Namul hal itu tidak mematahkan semangat para relawan program paliatif untuk selalu mendampingi si penderita penyakit atau keluarga penderita dengan cara memberikan dorongan semangat baik secara moril, dukungan psikologis maupun penguatan secara spiritual. Selain itu para relawan juga berkomitmen untuk selalu mendampingi si penderita atau keluarga penderita untuk tetap semangat menjalani proses pengobatan dan tahap penyembuhan serta mengajarkan kepada penderita maupun keluarga penderita untuk selalu berpikir positif.

Berdasarkan analisis situasi dan permasalahan serta metode pelaksanaan yang telah dijelaskan pada bab sebelumnya, maka kegiatan pengabdian kepada masyarakat ini berupaya untuk meningkatkan kapasitas perempuan sebagai relawan program paliatif khususnya dari Ibu-Ibu Tim Penggerak dan Anggota PKK dari Desa Ngembung dan Desa Kambingan Kecamatan Cerme Kabupaten Gresik dan tumbuhnya desa perintis program paliatif di Kecamatan Cerme Kabupaten Gresik. Tujuan utama dari kegiatan ini adalah agar para ibu-ibu yang menjadi relawan program paliatif menjadi lebih faham dan lebih sadar mengenai program paliatif serta mengetahui bahwa perempuan memiliki potensi yang tinggi untuk menjadi relawan dan terlibat langsung dalam program paliatif karena perempuan memiliki sisi emosional dan naluri yang berbeda dengan laki-laki sehingga perempuan lebih cocok untuk menjadi relawan program paliatif. Karena itu kegiatan pengabdian masyarakat ini berusaha mencapai tujuannya dengan melakukan pelatihan atau pemberian ceramah dan pembuatan modul bagi peserta sebagai pedoman ketika terlibat sebagai relawan program paliatif.

Dalam upaya menyelesaikan permasalahan mengenai tingginya tingkat kematian akibat penyakit serius dan perlunya dilakukan perawatan paliatif yang dianggap dapat meningkatkan kualitas hidup pasien namun disatu sisi jumlah tenaga kesehatan perawat pariatif yang terbatas, maka sudah seharusnya program paliatif ini melibatkan dan memanfaatkan potensi yang ada di masyarakat, yakni orang-orang yang diberi pelatihan 
mengenai pentingnya program paliatif sehingga dapat menambah jumlah perawat pariatif di lingkungan terdekat. Namun kenyataan yang ada di lapangan banyak masyarakat yang belum mengetahui tentang program ini ataupun kalau dilakukan belum bisa secara optimal karena kurangnya edukasi tentang program paliatif yang didapat masyarakat khususnya ibu-ibu yang menjadi relawan. Mereka belum tahu bagaimana cara perawatan palitif dilakukan, penyakit apa saja yang menjadi bagian dari program paliatif yang bias ditangani oleh relawan serta bagaimana alternatif solusi jika si pasien tidak mau mengkomunikasikan ke relawan mengenai penyakitnya. Hal ini dikarenakan beberapa hal, diantaranya: 1) Kurangnya sosialisasi atau pengenalan ke masyarakat mengenai program paliatif dari pemerintah atau dinas terkait sehingga masyarakat masih asing dengan program tersebut; 2) Belum adanya pelatihan yang diberikan ke masyarakat tentang program paliatif yang membuat masyarakat merasa tidak yakin atau tidak pantas untuk bisa terlibat menjadi relawan program paliatif; 3) Masyarakat sekitar atau lingkungan terdekat dari pasien beranggapan bahwa apabila ada tetangganya yang sakit atau bagaimana tidak berhak untuk mengetahui atau bahkan terlalu ikut campur didalamnya, anggapan seperti inilah yang dapat menghambat jalannya program paliatif yang dilakukan oleh masyarakat sekitar atau para relawan.

Dengan melihat hal-hal di atas dan telah terlaksananya kegiatan pengabdian masyarakat, maka hasil yang dicapai pada kegiatan ini adalah pemahaman masyarakat khususnya ibu-ibu yang menjadi relawan program paliatif ini telah bertambah dan meningkatnya kapasitas atau keterlibatan Ibu-Ibu Tim Penggerak dan Anggota PKK di Desa Ngembung dan Desa Kambingan Kecamatan Cerme Kabupaten Gresik. Ibu-Ibu dari dua desa tersebut sudah mengerti dan memahami tentang pentingnya program paliatif dan mereka mampu serta pantas untuk menjadi relawan program paliatif. Untuk hasil berikutnya para Ibu-Ibu dari kedua desa tersebut mau mempelajari modul yang diberikan, mengimplementasikan ilmu yang sudah didapatkan selama mengikuti pelatihan/ceramah pada kegiatan pengabdian masyarakat ini serta membagi ilmunya kepada masyarakat luas.

\section{PENUTUP}

\section{Simpulan}

Berdasarkan hasil pelaksanaan kegiatan pengabdian masyarakat yang telah dilaksanakan di dua desa tersebut, dapat ditarik beberapa pada umumnya masyarakat belum mengetahui mengenai adanya program paliatif yang selama ini sudah ada. Hal ini disebabkan karena kurang adanya sosialisasi yang dilakukan oleh pemerintah atau dinas terkait maupun edukasi yang diberikan ke masyarakat sebagai relawan program paliatif yang potensial. Namun selama ini masyarakat secara naluri sudah melaksanakan tindakan paliatif yakni berupa menanyakan kabar kepada si penderita atau kelurga penderita, memberikan dorongan semangat untuk menjalani pengobatan ataupun menyarankan rumah sakit tempat berobat untuk membantu percepatan proses penyembuhan penyakitnya. Untuk menjawab permasalahan di atas perlu diadakan pelatihan dan pengembangan kapasitas kepada perempuan Ibu-Ibu Tim Penggerak dan Anggota PKK yang menjadi sasaran dalam pengabdian masyarakat ini tentang arti pentingnya melakukan tindakan program paliatif untuk lingkungan terdekat sekitar dan memberikan pemahaman bahwa mereka semua mampu untuk menjadi relawan dalam kegiatan paliatif. Ibu-Ibu Tim Penggerak dan Anggota PKK sebagai sasaran dalam kegiatan pengabdian masyarakat ini adalah dari Desa Ngembung dan Desa Kambingan 
Kecamatan Cerme Kabupaten Gresik. Tim paliatif adalah tim yang tediri dari dokter umum, dokter spesialis, dokter paliatif, perawat, pelaku perawat, apoteker, psikolog, rohaniawan, terapis dan relawan. Target tujuan dari kegiatan pengabdian masyarakat ini adalah secara umum meningkatkan kapasitas ibu-ibu PKK agar siap menjadi relawan program paliatif dan secara khusus, target tujuan dari kegiatan pengabdian masyarakat adalah agar kelompok sasaran mampu memahami pentingnya dukungan psikologis dan psikis, serta penanganan program paliatif yang menjadi tupoksi relawan program paliatif.

\section{Saran}

Dari beberapa kesimpulan di atas, pengabdian masyarakat ini terdapat beberapa saran diantaranya: 1) Perlu adanya sosialisasi atau pelatihan dan pembinaan yang dilakukan oleh dinas terkait tentang program paliatif sehingga masyarakat bisa mengetahui program paliatif secara lebih menyeluruh, detail dan mendalam; 2) Perlu adanya perhatian dan campur tangan dari pihak pemerintah kabupaten, kecamatan maupun pemerintah desa/kelurahan untuk memberikan payung hukum yang jelas dan sah. Misalnya dengan pembuatan pembentukan tim paliatif desa melalui Surat Keputusan di desa yang menjadi follow-up program. Idealnya, tim paliatif ini ada mulai di tingkat desa, kecamatan, hingga kota/Kabupaten dan bahkan provinsi dan pusat. Sehingga pelayan paliatif dan juga relawan-relawan yang terlibat mempunyai status legal formal yang jelas dan sah. Di tingkat desa sendiri, dengan adanya SK seorang relawan program paliatif menjadi resmi dan diakui oleh pemerintah desa dan selanjutnya masyarakat; 3) Perlu adanya perhatian dan campur tangan dari pihak Kepala Desa dan Bidan Desa dalam mendampingi relawan program paliatif. Walaupun sebenarnya layanan atau sikap masyarakat terhadap penderita penyakit yang masuk dalam penyakit tidak menular namun mematikan termasuk penyakit degeneratif, dan terutama penyakit yang tidak bisa disembuhkan ini telah banyak dilaksanakan dan mendapat perhatian, namun belum terkoordinasi, dan lebih sering dilakukan secara incidental, sporadic dan ala kadarnya. Atau dengan kata lain kurang terlembaga. Saran-saran ini semoga dapat membuat outcome Program Pengabdian Masyarakat ini dapat terus berlanjut dan berkembang ke masyarakat luas di luar dua desa yang menjadi sasaran pengabdian masyarakat ini.

\section{DAFTAR PUSTAKA}

Departemen Kesehatan RI, 2017. Kementerian Kesehatan Ajak Masyarakat Cegah dan Kendalikan Kanker dalam http://www.depkes.go.id/article/print/ 17020200002/kementerian-kesehatan-ajak-masyarakat-cegah-dankendalikan-kanker.html

Jawa Pos, 26 Desember 2017

Modul 6 Communication. A Guide to Hospice Volunteer Training in British Columbia. 2008. British Columbia Hospice Palliative Care Association.

Modul TOT Paliatif Kanker Bagi Tenaga Kesehatan, Kementerian Kesehatan Republik Indonesia tahun 2016 Palliative Care Victoria Training Kit tahun 2012. Sumber https://www.pallcarevic.asn.au/ Training Manual for Hospice Palliative Care Volunteers. Ottawa, ON: Canadian 
Nugroho, Riant.D.2008. Gender dan Strategi Pengarusutamaannya di Indonesia. Yogyakarta: Pustaka Pelajar.

Sofiana, Liena. 2016. Analisis Tingkat Kepatuhan Hand Hygiene Perawat dalam Pencegahan Infeksi Nosokomial. Yogyakarta. FKM. Universitas Ahmad Dahlan.

Sunaryadi, 2017. Usulkan Prodi Spesialis Paliatif, FK Unair Sudah Beberapa Kali Membahas dalam https://www.jawapos.com/pendidikan/17/02/2017/usulkanprodi-spesialis-paliatif-fk-unair-sudah-beberapa-kali-membahas

Wymer, W., "Gender Differences in Social Support in The Decision to Volunteer". International Review on Public and Nonprofit Marketing, May 2012, Volume 9, Issue 1,pp 19-26. 